Acta Theriologica 43 (3): 293-300, 1998.

PL ISSN 0001-7051

\title{
Cranial and dental abnormalities of the endangered red wolf Canis rufus
}

\author{
Nicholas E. FEDEROFF* and Ronald M. NOWAK
}

Federoff N. E. and Nowak R. M. 1998. Cranial and dental abnormalities of the endangered red wolf Canis rufus. Acta Theriologica 43: 293-300.

Skulls of 3 captive-raised female endangered red wolves Canis rufus Audubon and Bachman, 1851 exhibited severe malocclusion of the jaws. Cranial and dental abnormalities (including crowding of upper toothrows, and an extra tooth behind the lower left $\mathrm{M}_{3}$ in one of the three mandibles) were also evident. Ratios of alveolar length of maxillary toothrow to maximum width across the outer sides of crowns of $\mathrm{P}^{4}$ were significantly different $(p=0.008)$ compared to unaffected skulls. Significant differences were also evident when ratios of maximum width across inner edges of alveoli of $\mathrm{P}^{1}$ to alveolar length of maxillary toothrow and maximum width across outer sides of crowns of $\mathrm{P}^{4}$ were compared between the two groups. Although the three skulls all exhibited malocclusion, the abnormality expressed itself differently in relation to the effects to each skull. Captive inbreeding may increase the probability and frequency of expressing these anomalies, although inbreeding coefficients calculated for the wolves expressing malocclusion were not considered high $(0.0313-0.0508)$. A wild female red wolf specimen captured in 1921 in Arkansas also exhibited the malocclusion, although not as severely as in the captive females. This demonstrates that this trait was present in wild populations prior to, and not a result of, the captive breeding program.

Patuxent Wildlife Research Center, 11510 American Holly Drive, Laurel, MD 20708, USA (NEF); U.S. Fish and Wildlife Service, Washington, D.C. 20240, USA (RMN)

Key words: Canis rufus, cranial abnormalities, malocclusion, captivity, inbreeding

\section{Introduction}

The red wolf Canis rufus Audubon and Bachman, 1851, a North American species classified as critically endangered by the World Conservation Union (Baillie and Groombridge 1996), evidently disappeared in the wild by 1980 (Cohn 1987, Meese 1989). Efforts to capture the few remaining free-ranging red wolves in Texas and Louisiana began in the late 1960s. Of the hundreds captured, 43 were selected by morphological standards for inclusion into the captive breeding program (Waddell and Behrns 1996). Of these 43 red wolves, only 14 served as the foundation stock for the captive breeding program (Cohn 1987). By 1984, there were 50 red wolves in the program (Parker 1984), all of which were direct

*Present address: Environmental Protection Agency, Mail Code 7507C, 401 M St. SW, Washington, D.C. 20460 (USA) 
descendants of 13 of the original 14 founders. Red wolves have successfully been reintroduced to Alligator River National Wildlife Refuge in coastal North Carolina and to the Great Smoky Mountains National Park in Tennessee. At present, 64 to 88 individuals inhabit the wild and 192 are held in captivity (Waddell 1996).

Recent genetic analysis suggests that red wolves used to establish the recovery program accurately represent the composition of the pre-1940 wild population (Roy et al. 1996). The captive bred population may therefore be a fairly faithful genetic representation of animals that once roamed the wild. However, while Roy et al. (1996) also suggested a hybrid origin for the red wolf, other scientists have disagreed (Nowak and Federoff 1996). All available specimens indicate that the region from the Mississippi River to Pennsylvania and Florida was originally occupied by a single, distinctive kind of wild Canis. Cranial morphology was statistically very similar, both to Pleistocene populations in the same region and to modern red wolf populations just west of the Mississippi (Nowak and Federoff 1996). That there has been hybridization between the red wolf and coyote Canis latrans is not in dispute. However, there is no evidence that any of these populations originated through hybridization between the gray wolf (Canis lupus) and the coyote. In addition, Roy et al. (1996) do state that their genetic analysis cannot readily deduce the precise timing of hybridization nor the true origin of the red wolf. Nevertheless, both Wayne and Jenks (1991) and Roy et al. (1996) support continued protection of the red wolf.

Canids bred and raised in captivity can exhibit an assortment of morphological changes. These changes may be due to environmental factors, genetic factors, or a mixture of both. Recessive genes, typically hidden, might express themselves more frequently as a result of the captive breeding of highly related individuals. For example, Laikre and Ryman (1991) suggest that the occurrence of an apparently hereditary form of blindness in wolves was associated with inbreeding and that deleterious homozygous alleles may be fairly common in natural wolf populations. Recently, an eye abnormality, in the form of suspected progressive retinal atrophy, has also been reported in three male red wolves and is more than likely genetically based (C. Lucash, pers. comm.). Federoff (1996) suggests that cranial and dental abnormalities expressed in captive arctic wolves Canis lupus arctos, similar to that reported in a wild male arctic wolf from Ellesmere Island (Clutton-Brock et al. 1994), may be the result of a recessively inherited trait, possibly associated with increased levels of inbreeding. However, while natural inbreeding can occur in wild wolf populations, Smith et al. (1997) suggest that inbreeding in wild wolves may be relatively rare and that incest avoidance is an important constraint on gray wolf behavioral ecology and may be one of the primary reasons for dispersal from natal packs. Nevertheless, a similar condition to that reported by Federoff (1996) in arctic wolves has now been found to occur in red wolves, both in the wild and under captive breeding conditions, and is described here. 


\section{Material and methods}

Ten cranial measurements (Table 1), the same used by Nowak (1995), were taken from the skulls of three 19-month-old female red wolf littermates $472 \mathrm{~F}, 473 \mathrm{~F}, 474 \mathrm{~F}$; Slater Museum, University of Puget Sound, Tacoma, Washington, USA), observed to exhibit severe malocclusion, and from a series of 15 normal appearing female Canis rufus (consisting of the four female founders of the captive breeding program and 11 of their direct descendants). Relaxation of natural selective pressures, founder effect, and other changes associated with captivity may have influenced aspects of cranial morphology unrelated to the effects of the abnormality, although the degree of such influences are

Table 1. Skull measurements of three malocclusive captive 19 month old female red wolves (472F, $473 \mathrm{~F}, 474 \mathrm{~F})$ and a series of captive bred female C. rufus ( $n=15$, including four founders). *Measurements used by Nowak (1995).

\begin{tabular}{|c|c|c|c|c|}
\hline Skull measurements (mm) & $472 \mathrm{~F}$ & $473 \mathrm{~F}$ & $474 \mathrm{~F}$ & $\begin{array}{c}\text { Skull series } \\
(\text { mean } \pm 1 \mathrm{SD})\end{array}$ \\
\hline Greatest length* & 217.0 & 210.0 & 211.0 & $219.60 \pm 7.75$ \\
\hline Zygomatic width* & 120.0 & 116.0 & 110.0 & $117.60 \pm 3.14$ \\
\hline Alveolar length of maxillary toothrow $\left(\mathrm{P}^{1} \text { to } \mathrm{M}^{2}\right)^{*}$ & 69.0 & 64.2 & 68.0 & $73.90 \pm 2.87$ \\
\hline Maximum width across outer sides of crowns of $\mathrm{P}^{4} *$ & 71.0 & 65.7 & 62.7 & $67.38 \pm 1.32$ \\
\hline Maximum width across inner edges of alveoli of $\mathrm{P}^{1 *}$ & 31.0 & 27.1 & 6.5 & $26.29 \pm 1.29$ \\
\hline Width of frontal shield ${ }^{*}$ & 51.3 & 43.2 & 48.1 & $50.15 \pm 2.87$ \\
\hline Height from alveolus of $\mathrm{M}^{1}$ to lowest point of orbit* & 29.6 & 28.6 & 27.5 & $31.63 \pm 1.99$ \\
\hline Depth of jugal* & 12.0 & 11.9 & 10.7 & $13.27 \pm 1.26$ \\
\hline Crown length of $\mathrm{P}^{4 *}$ & 21.3 & 22.1 & 19.9 & $20.83 \pm 0.77$ \\
\hline Maximum crown width of $\mathrm{M}^{2 *}$ & 13.7 & 14.0 & 13.2 & $13.45 \pm 0.62$ \\
\hline Greatest diameter of tympanic bullae & 26.6 & 24.2 & 24.4 & - \\
\hline Anteroposterior length of $\mathrm{C}^{1}$ & 11.3 & 12.2 & 11.5 & - \\
\hline Crown length of $\mathrm{P}^{3}$ & 13.9 & 14.2 & 13.0 & - \\
\hline Maximum crown width of $\mathrm{M}^{1}$ & 20.2 & 20.4 & 18.4 & - \\
\hline Alveolar length from $\mathrm{P}_{1}$ to $\mathrm{M}_{3}$ & 89.7 & 88.2 & 88.1 & - \\
\hline Mandibular depth taken between $\mathrm{P}_{3}$ and $\mathrm{P}_{4}$ & 20.8 & 19.2 & 19.3 & - \\
\hline Crown length of $\mathrm{P}_{4}$ & 14.1 & 14.6 & 12.5 & - \\
\hline Crown length of $\mathrm{M}_{1}$ & 24.2 & 23.7 & 22.2 & - \\
\hline
\end{tabular}

unknown (Wolfgramm 1893/4). The abnormal specimens were produced in the captive breeding program, thus only adult female crania descending from the female founders and the female founders themselves were measured and used for comparisons. Ratios were calculated from these measurements and the groups (unaffected and malocclusive) were statistically compared using a $t$-test. Inbreeding coefficients were calculated from stud book records using the SAS program INBREED (1996).

\section{Results}

The three abnormal female skulls from the captive breeding program exhibited severe malocclusion of the jaws resulting in cranial and dental abnormalities. The 

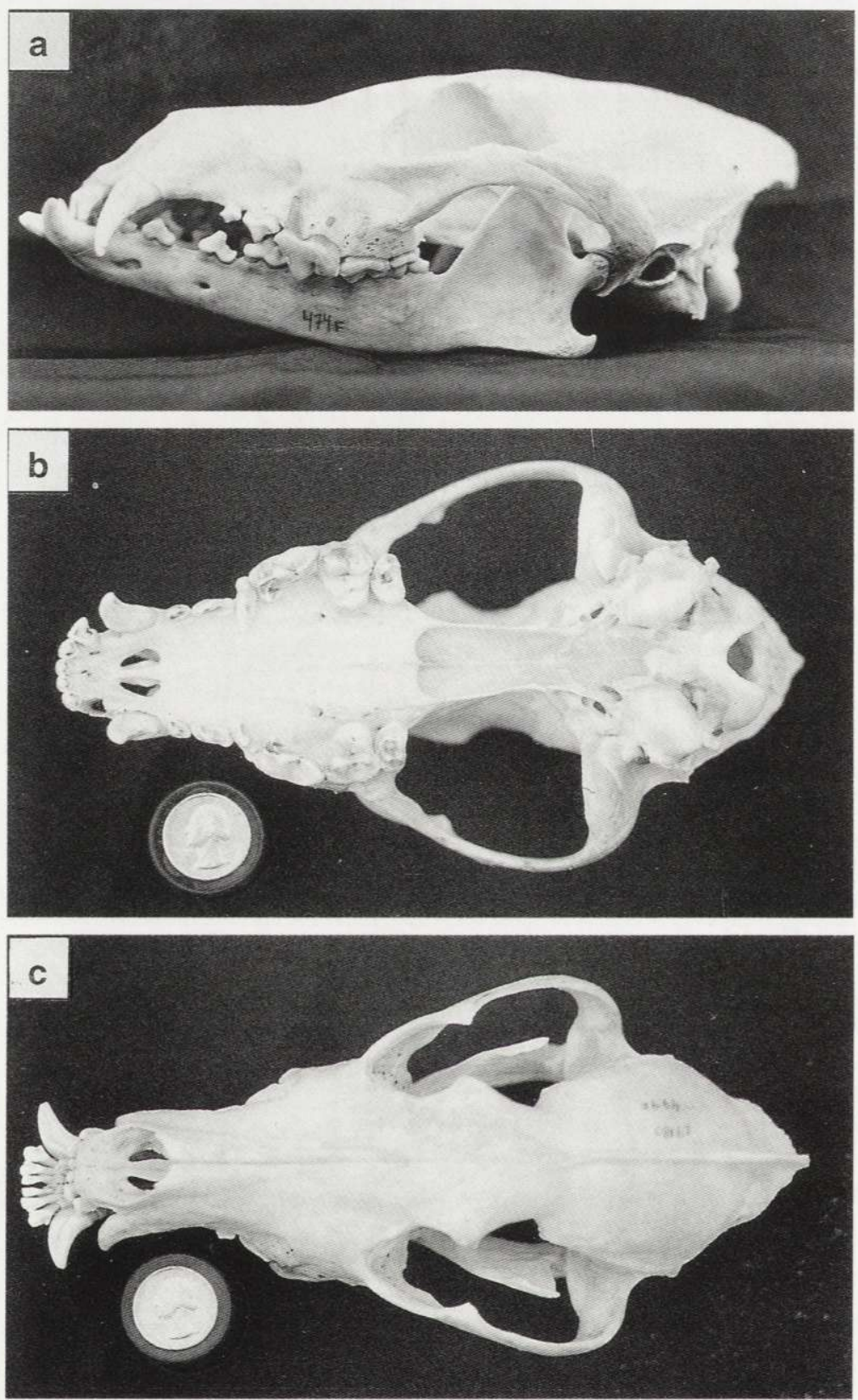

Fig. 1. (a) Left side view of a captive female red wolf $C$. rufus skull (474F) exhibiting the malocclusion, windows in the bone overlying the roots of $\mathrm{P}^{4}$ and $\mathrm{M}^{1}, \mathrm{P}^{2}$ as a small single-rooted tooth, and $\mathrm{P}^{1}$ missing altogether. (b) Dorsal view (474F) showing extreme malocclusion. (c) Palatal view (473F) showing shortening of upper toothrow resulting in crowded teeth and compacted $\mathrm{P}^{3}$. 
characteristics of the malocclusion were evident in the portion of the rostrum anterior to the upper fourth premolars $\left(\mathrm{P}^{4}\right)$. The facial regions were foreshortened and undershot by the mandible. A mis-alignment of the upper third premolars $\left(\mathrm{P}^{3}\right)$ was evident as well (Fig. 1). The malocclusive distance, measured from the most anterior point of $\mathrm{I}^{1}$ forward to the most anterior point of $\mathrm{I}_{1}$, ranged from 10.7 to $13.7 \mathrm{~mm}$ with a mean distance of $12.3 \mathrm{~mm}$. The distance was also measured from the most anterior point of the pre-maxilla to the most anterior point of the mandible and ranged from 8.4 to $8.8 \mathrm{~mm}$ with a mean distance of $8.6 \mathrm{~mm}$. A comparison of ratios of alveolar length of toothrow to the maximum width across the outer sides of the crowns of $\mathrm{P}^{4}$ taken from measurements from the three abnormal skulls and from the normal series showed a statistically significant difference $(p=0.008)$ between the two skull groups in relation to those ratio parameters (Fig. 2). Significant differences between the two groups were also evident in the ratios of maximum width across inner edges of alveoli of $\mathrm{P}^{1}$ to alveolar length of maxillary toothrow and maximum width across outer sides of crowns of $\mathrm{P}^{4}$.

Dental, cranial, and mandibular abnormalities associated with the malocclusion were quite evident. Skull $472 \mathrm{~F}$ exhibited upper toothrow crowding, although the lower teeth appeared normally spaced. The upper third incisors met the lower canines and struck the mandible just before alveoli of the lower incisors. The lower

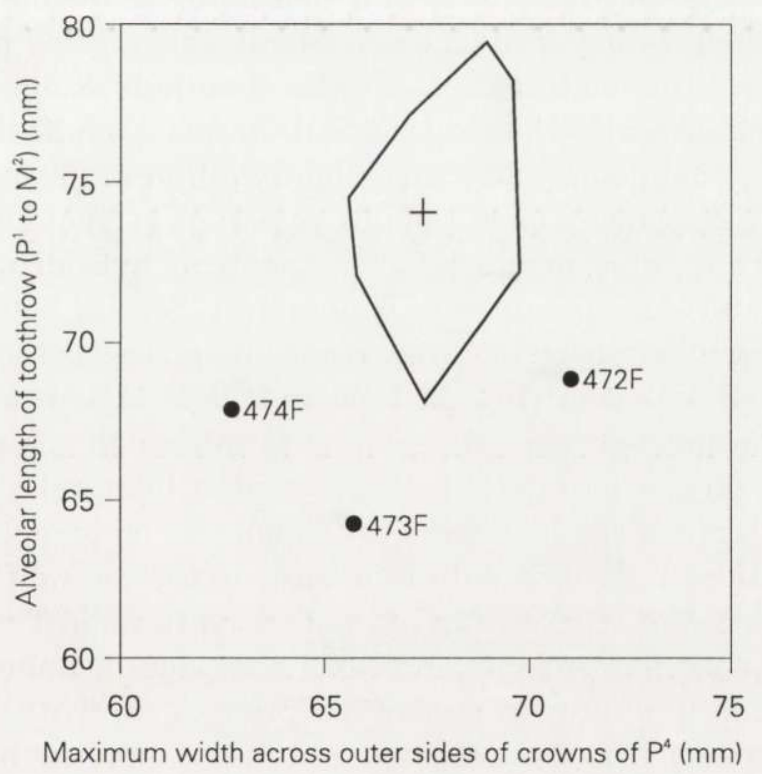

Fig. 2. Bivariate position comparison of cranial measurements (alveolar length of toothrow and maximum width across outer sides of crowns of $\left.\mathrm{P}^{4}\right)$ in a series of female captive $C$. rufus $(n=15)$ and three malocclusive captive red wolves $(472 \mathrm{~F}, 473 \mathrm{~F}, 474 \mathrm{~F})$. 
incisors extended forward horizontally, rather than vertically, and the mandible had a relatively narrow spread with all teeth angled outward. Skull $473 \mathrm{~F}$ exhibited characteristics similar to skull $472 \mathrm{~F}$, although the lower teeth were more crowded, especially $\mathrm{M}_{2}$. The upper toothrow was very crowded as well and $\mathrm{P}^{3}$ was set almost perpendicular to $\mathrm{P}^{2}$. An extra tooth behind the lower left $\mathrm{M}_{3}$ was also present. The frontal shield processes were also not normally developed. $\mathrm{P}^{3}$ was not as severely crowded in skull $474 \mathrm{~F}$, although $\mathrm{P}^{2}$ was a small single-rooted tooth, and $\mathrm{P}^{1}$ was missing altogether. The mandible appeared very narrow, and the outer roots of $\mathrm{P}^{4}$ and $\mathrm{M}^{1}$ were unusually exposed as well. All three skulls expressed a slight Roman nose feature, although it was most pronounced in skull $474 \mathrm{~F}$. The postorbital process on the jugal was curved inward rather than extending upward and the symphisis of the lower jaws presented a horizontally flattened area where the upper incisors strike in all three skulls.

\section{Discussion}

The effects on dental parameters and associated abnormalities in the affected red wolves seemed to be more extreme than in affected arctic wolves (Federoff 1996), although overall cranial proportions (greatest length to zygomatic width) seemingly were not affected in these red wolves as they were in the malocclusive arctic wolves. The primary effect was in a shortening of the upper toothrows and the resulting tooth crowding, although each skull was affected in a dimensionally different way. When the measurements of the abnormal skulls were compared to the unaffected female series means $( \pm 2 \mathrm{SD})$, it was evident that the way each skull responded to the abnormality was slightly different (Table 1). Although all of the abnormalities present in the skulls apparently resulted from the malocclusive condition, the extent to which factors involving hybridization and captivity may have influenced skull parameters is unknown (Strebel 1905). Similar dental anomalies (shortening of upper toothrow resulting in crowded teeth, displaced $\mathrm{P}^{4}$, and windows in the bone overlying the roots of $\mathrm{P}^{4}$ and $\mathrm{M}^{1}$ ) have been reported for captive raised coydog hybrids (Mengel 1971), although no malocclusion was described. Buchalczyk et al. (1981) have reported a bilateral skeweness of $\mathrm{P}^{3}$ in skulls collected from wolves in Poland, although the occurrence of malocclusion was also not mentioned. Historic data from early in the red wolf recovery program (V.G. Henry, pers. comm.) concerning red wolves captured in Texas and Louisiana and their subsequent descendants indicates that dental anomalies (polydonty) were evident in the free-ranging population prior to captivity. Vila et al. (1993) suggest that alterations in the dentition are fairly common in wild wolf populations. No such anomalies were reported by Iljin (1941) for wolf-dog crosses.

A high incidence of malocclusion has also been reported in red foxes Vulpes vulpes from the Netherlands (Bouwmeester et al. 1989), and more recently, 
Meijaard and van Bree (1994) have described the abnormality in populations of red fox in Australia. The foxes exhibited a pronounced protrusion of the maxillary incisors over the mandibular incisors, a result of a shortening of the front part of the mandibles. The authors also suggest that the high occurrence of the abnormality was likely a result of a small, isolated gene pool and a recessive mode of inheritance. In contrast to the condition in these red foxes, the abnormality in wolves is associated with a shortened rostrum, the mandible being of normal length.

Two living captive male red wolves (481M, 687M), both from different litters, also express the abnormal trait, implying the mode of inheritance is not linked to the sex of the affected animal. Results from a pedigree analysis using the official red wolf studbook (Waddell and Behrns 1996) suggest that this abnormal condition is genetic, and is most probably the result of a recessively inherited trait, possibly expressed more frequently through increased levels of inbreeding in captivity. However, inbreeding coefficients were low in comparison to captive arctic wolves (Federoff 1996). Coefficients for malocclusive captive red wolves ranged from 0.0313 to 0.0508 . These coefficients may actually be higher depending on the relatedness of the founders. Seven of the ten founders $(70 \%)$ represented in the malocclusive pedigree were captured in Texas ( $85.7 \%$ from Jefferson county, Texas) and three of the ten founders $(30 \%)$ represent two areas in Louisiana (Cameron and Calcasieu Parish). The malocclusive pedigree represents $76.9 \%$ of the original 13 founders and $0.72 \%$ of the captive population expressed the abnormality thus far.

A wild female red wolf specimen (National Museum of Natural History, skull \#236542) captured in 1921 in Arkansas also exhibited malocclusion. Cranial measurements taken from this specimen were compared with a series of wild females $(n=52)$ taken between 1919 and 1929 (Nowak 1979). The malocclusive specimen was within \pm 2 SD of the 1919 to 1929 series mean in relation to the cranial parameters measured. The wild specimen expressed identical features as the malocclusive captive specimens. However, the severity of malocclusion in the wild specimen was not as great as that expressed in the captive females, although the forehead exhibited more of a bulging appearance and the molars were extremely worn down, apparently caused by the abnormality. The existence of this specimen demonstrates that this trait was present in wild populations prior to, and not a result of, the captive breeding program.

Acknowledgements: The authors would like to thank W. Waddell, S. Behrns, M. Morse, G. Henry, R. Ring, C. Lucash, and J. Gilbreath for important wild and captive lineage information; G. Shugert and D. Paulson (Slater Museum, University of Puget Sound) for loan of the affected skulls; L. Gordon (National Museum of Natural History, Smithsonian Mammalogy Department); K. Boone (Patuxent Wildlife Research Center) for excellent figure preparation; L. Garrett and P. Manning (Patuxent Wildlife Research Center library); and J. Eisemann, D. Pennock, D. W. Sparling, I. L. Brisbin, Jr, and L. D. Mech for critical review of the manuscript. 


\section{References}

Audubon J. J. and Bachman J. 1851. The quadrupeds of North America. New York, vol. 2: 1-334.

Baillie J. and Groombridge B., eds 1996. 1996 IUCN Red List of threatened animals. IUCN, Gland, Switzerland: $1-368$.

Bouwmeester J., Mulder J. L. and van Bree P. J. H. 1989. High incidence of malocclusion in an isolated population of the red fox (Vulpes vulpes) in the Netherlands. Journal of Zoology, London 219: 123-136.

Buchalczyk T., Dynowski J. and Szteyn S. 1981. Variations in the number of teeth and asymmetry of the skull in the wolf. Acta Theriologica 26: 23-30.

Clutton-Brock J., Kitchener A. C. and Lynch M. M. 1994. Changes in the skull morphology of the Arctic wolf, Canis lupus arctos, during the twentieth century. Journal of Zoology, London 223: 19-36.

Cohn J. P. 1987. Red wolf in the wilderness. Bioscience 37: 313-316.

Federoff N. E. 1996. Malocclusion in the jaws of captive bred Arctic wolves (Canis lupus arctos). Canadian Field-Naturalist 110: 683-687.

Iljin N. A. 1941. Wolf-dog genetics. Journal of Genetics 42: 359-414.

Laikre L. and Ryman N. 1991. Inbreeding depression in a captive wolf population. Conservation Biology 5: 33-40.

Meese G. M. 1989. Intensified efforts for red wolves are paying off. Endangered Species Update VI (10): $26-27$

Meijaard E. and van Bree P. J. H. 1994. Cases of dental malocclusion in populations of red foxes (Vulpes vulpes) in the state of Victoria, Australia. Zeitschrift für Säugetierkunde 59: 378-379.

Mengel R. M. 1971. A study of dog-coyote hybrids and implications concerning hybridization in Canis. Journal of Mammalogy 52: 316-336.

Nowak R. M. 1979. North American quarternary Canis. Monograph no. 6. Museum of Natural History. University of Kansas, Lawrence: 1-154.

Nowak R. M. 1995. Another look at wolf taxonomy. [In: Ecology and conservation of wolves in a changing world. L. N. Carbyn, S. H. Fritts and D. R. Seip, eds]. Proceedings of the 2nd North American Wolf Symposium, August 24-27, 1992. Canadian Circumpolar Institute, University of Alberta, Edmonton: 375-398.

Nowak R. M. and Federoff N. E. 1996. Systematics of wolves in Eastern North America. Wolves of America Conference Proceedings, November 14-16, 1996. Defenders of Wildlife, Washington, D.C.: $187-203$

Parker W. T. 1984. Seeking a home for the red wolf. Endangered Species Technical Bulletin 15: 3.

Roy M. S., Geffen E., Smith D. and Wayne R. K. 1996. Molecular genetics of pre-1940 red wolves. Conservation Biology 10(5): 1413-1424.

SAS. 1996. SAS Institute Inc., version 6.11, Cary, North Carolina.

Smith D., Meier T., Geffen E., Mech L. D., Burch J. W., Adams L. G. and Wayne R. K. 1997. Is incest common in gray wolf packs? Behavioral Ecology 8(3): 384-391.

Strebel R. 1905. Die deutschen Hunde, und ihre Abstammung. Elije Ertel Derlag, München: 1-160.

Vila C., Urios V. and Castroviejo J. 1993. Tooth losses and anomalies in the wolf (Canis lupus). Canadian Journal of Zoology 71: 968-971.

Waddell W. T. and Behrns S. K. 1996. Red wolf 1995 International Stud Book. Point Defiance Zoo and Aquarium, Tacoma, Washington: 1-49.

Waddell W. T. 1996. Red wolf population. Red Wolf Newsletter 9: 5

Wayne R. K. and Jenks S. M. 1991. Mitochondrial DNA analysis implying extensive hybridization of the endangered red wolf Canis rufus. Nature 351: 565-568.

Wolfgramm A. 1893/4. Die Einwirkung der Gefangenschaft auf die Gestaltung des Wolfsschädels. Zoologische Jahrbücher, Jena: 773-822.

Received 30 July 1997, accepted 5 January 1998. 